\title{
Lingkungan Keluarga Sebagai Awal Pengembangan Kewirausahaan Islam
}

Fattah Setiawan Santoso*

Universitas Cokrominoto Yogyakarta

*Penulis Koresponden, email: fssanto20@gmail.com

\begin{abstract}
Abstrak
Bagi umat muslim, kewirausahaan merupakan bagian dari proses ikhtiar dalam rangka ibadah dalam mencari keridhaan Allah SWT untuk mencapai keberuntungan tidak saja dalam kehidupan duniawi tetapi juga untuk diakhirat kelak. Tulisan ini bermaksud menggali lebih lanjut tentang peran keluarga dalam pengembangan karakter dan minat berwirausaha secara Islami dalam kajian literature. Kewirausahaan memerlukan karakter dan motif yang khas yang diperlukan dalam keberhasilannya. keluarga bisa mempengaruhi semua yang bisa dipersiapkan untuk seseorang melakukan kewirausahaan. Lingkungan pendidikanj pertama ini juga bisa memberikan pengetahuan dan keterampilan yang sesuai dengan bidang kewirausahaan. Hal itu akan lebih baik apabila orang tua juga telah memilikinya.
\end{abstract}

Kata Kunci:kewirausahaan, Islam, pendidikan keluarga

\begin{abstract}
For Muslims, entrepreneurship is part of an endeavor process in the framework of worship in seeking the pleasure of Allah SWT to achieve good luck not only in worldly life but also for the hereafter. This paper intends to explore more about the role of the family in character development and interest in Islamic entrepreneurship in literature studies. entrepreneurship requires a distinctive character and motives required for its success. family can influence all that can be prepared for someone to do entrepreneurship. This first educational environment can also provide knowledge and skills appropriate to the field of entrepreneurship. It will be better if the parents also have it.
\end{abstract}

Keywords: entrepreneurship, Islam, family education

\section{Pendahuluan}

Kewirausahaan di kalangan masyarakat barat juga dikenal dikenal dengan entreprenuership. Wirausahawan dengan demikian menjadi entrepreneur. Friences menjelaskan asal katanya dari bahasa Perancis. Entreprendre berarti melakukan (to undertake) atau mencoba (trying). Kata entreprendre diartikan juga sebagai diantara pengambil atau perantara.(Frinces 2011) 
Aktivitas ini berkaitan dengan kejiwaan seseorang dalam berusaha. Seseorang tergolong sebagai wirausahawan apabila orang tersebut mempunyai suatu motif atau keinginan tertentu untuk memperoleh keberhasilan yang diperhitungkan, direncanakan, dan dikerjakan secara teratur dan terorganisasi. Dalam Islam, Bahri menunjuknya sebagai aktivitas bisnis dan bertransaksi konsep dan tata caranya sudah diatur dalam alQur'an dan Hadits. Al-Quran sebagai panduan hidup manusia, memberikan pedoman syariah bagi para entrepreneur untuk bekerja (Bahri 2018).

Di dalam diri wirausahawan memiliki sikap pantang mundur dalam melakukan segala macam usaha sampai akhirnya bisa dilakukan suatu evalusi secara objektif. seperti yang diutarakan oleh Arifin, bagi umat muslim, implementasi dari motif atau keinginan itu sendiri dimaksudkan sebagai suatu proses ikhtiar dalam rangka ibadah dalam mencari keridhaan Allah SWT untuk mencapai keberuntungan tidak saja dalam kehidupan duniawi tetapi juga untuk diakhirat kelak (Arifin 2003).

Kehidupan santri di pesantren bahkan telah ditempa dengan pendidikan kewirausahaan Islam (Nadjib H. et al. 2019; Nugroho 2017). Kemandirian dalam pesantren telah mengarahkannya sebagai pengambil resiko (risk taker) dengan meninggalkan kenyamanan di kehidupan keluarga dengan memilih tinggal dan belajar di pesantren (Kamal dan Thoyyibah 2020). Pendidikan ekstra kurikuler seperti Hizbul Wathan juga berdampak pada sikap madiri yang menjadi karakter penting dalam pribadi wirausaha (Prastomo et al. 2019). Meski demikian, lingkungan keluarga tetap memiliki andil besar dalam pengembangan kewirausahaan dalam diri seseorang (Suhartini 2011). Oktarina dkk (2019) bahkan tegas menyimpulkan lingkungan keluarga berpengaruh positif terhadap minat berwirausaha seseorang. Apabila Keluarga mendukung kewirausahaaan, maka minat seseorang semakin besar, demikian pula sebaliknya.

Rasulullah pun telah memberikan teladan bagaimana kehidupan keluarganya telah memberikan dasar-dasar penting dalam berniaga setelah dewasa. Kamaluddin menceritakan sejak kecil sebagai pengembala kambing untuk meringankan beban ibu dan paman setelah ayahnya wafat. Di usia 12 tahun telah berdagang antar kota Mekkah dan Madinah mengikuti pamannya. Profesi yang dilanjutkan hingga dewasa dengan cerdas, ulet, dan jujur hingga dikenal sebagai al-Amin.(Kamaluddin Kamaluddin 2019)

Tulisan ini bermaksud menggali lebih lanjut tentang peran keluarga dalam pengembangan karakter dan minat berwirausaha secara Islami. Melalui kajian literature diharapkan dapat dirumuskan bagaiamana 
pendidikan keluarga bisa mengembangkan kewirausahaan. Untuk itu dijelaskan terlebih dahulu tentang apa itu wira usaha termasuk karakter dan motif yang diperlukan menuju keberhasilan berwirausaha. Di akhir kemudian dibahasa bagaiamana keluarga bisa mempengaruhi semua yang bisa dipersiapkan untuk seseorang melakukan kewirausahaan.

\section{Metode}

Penelitian ini termasuk dalam kajian literatur. Eksplorasi tersebut tidak dimaksudkan untuk menguji suatu hipotesis maupun teori tertentu, melainkan penelusuran untuk menemukan pemahaman baru mengenai fenomena yang dikaji terutama dalam pengembangan lingkungan keluarga sebagai wahana pendidikan kewirausahaan Islam. Dalam prosesnya diawali dengan Pengumpulan literature yang relevan menuju reduksi dan penampilannya sehingga bisa diambil kesimpulan dan verifikasi.

\section{Kewirausahaan Islam}

Istilah dan dari entrepreneurship atau wirausaha diawali oleh pemikiran dan studi yang dilakukan oleh para ekonom terkemuka apad abad ke 18 dan ke 19. Para ekonom seperti Richard Cantillon dan Joseph B. Say dan Joseph Schumpeter telah memberikan definisi tentang wirausaha yaitu seseorang yang siap untuk mengambil risiko-risiko dan dia berbeda dari orang-orang yang menyuplai modal dengan harapan sebuah keuntungan yang tetap. Richard Cantillon kemudian kata-kata tersebut diberi makna sebagai orang-orang yang melaksanakan atau melakukan sesuatu yang berisiko dari usaha- usaha baru.(Frinces 2011)

Menurut Zimmerer dan Scrbrough wirausahawan adalah orang yang mampu menciptakan bisnis baru dengan mengambil risiko dan ketidakpastian demi peruntungan dan pertumbuhan dengan cara mengidentifikasi peluang dan menggabungkan sumber daya yang diperlukan untuk mendirikannya.(Fahmi n.d.; Suryana 2014) Titik tekan dalam pengertian demikian muncul sebagai karakter seseorang yang tangguh, siap bekerja keras dengan memecahkan masalah dan memanfaatkan peluang yang dihadapi setiap hari cara kerja keras saat membentuk dan mengembangkan usaha baru. Dengan mengandalkan daya dalam diri sendiri berupa kreatifitias inovatif sebagai minat dasar dan sumber daya penggerak dalam proses dan perjuangan menghadapi tantangan berusaha. Hal yang dipertegas oleh Drucker. Konsep kewirausahaan merujuk pada sifat, watak, dan ciri-ciri yang melekat pada seseorang yang mempunyai kemauan keras untuk mewujudkan gagasan inovatif ke dalam dunia usaha yang nyata dan dapat mengembangkannya 
dengan tangguh.

Rye menjelaskan wirausahawan merupakan seorang yang mengorganisasikan dan mengarahkan usaha baru.(Basrowi 2011) Tekanannya pada kemampuan seseorang dalam tata kelola namun samasama mengandalkan kemampuan pribadi seseorang untuk menciptakan sesuatu yang baru, berbeda dari yang lain. Perbedaaan penemuan dengan yang sudah ada sebelumnya termasuk dalam hal ini.

Secara etimologi bahasa Indonesia, kewirausahaan berasal dari kata wira dan usaha. Wira berarti peluang, pahlawan, manusia unggul, teladan, berbudi luhur, gagah berani, dan berwatak agung. Sedangkan menurut Kamus Besar Bahasa Indonesia dari Rusdiana (2014), wirausaha adalah orang yang pandai atau berbakat mengenali produk baru, menentukan cara produksi baru, menyusun operasi untuk mengadakan produk baru, mengatur permodalan operasinya, serta memasarkannya. Kewirausahaan kemudian bisa bermakna sebagai usaha kemampuan (an ability) yang didalamnya termasuk dalam artian usaha (effort), aktivitas, aksi, tindakan dan lain sebagainya untuk menyelesaikan suatu tugas.

Secara bahasa, kekuatan karakter yang dibutuhkan dalam kewirausahaan masih mengikuti yang berkembang di dalam literatur ekonomi barat. Hal itu juga diiyakan sebagian besar pakar Indonesia. Gitosardjono (2013) mengartikan wirausahawan adalah orang yang mendirikan, mengelola, mengembangkan dan melembagakan perusahaan miliknya atau kemampuan yang dimiliki oleh seseorang untuk melihat dan menilai kesempatan bisnis, mengumpulkan sumber daya yang dibutuhkan untuk mengambil tindakan yang tepat dan mengambil keuntungan dalam rangka meraih sukses.

Peran dari wirausahawan bagi Suryana memiliki dua peran yaitu penemu dan perencana strategis. Sebagai penemu wirausaha menemukan dan menciptakan produk baru, teknologi dan cara baru, ide-ide baru dan organisasi usaha baru. Sedangkan sebagai perencana, wirausaha berperan merancang usaha baru, merencakan strategi perusahaan baru, merencakan ide-ide dan peluang dalam perusahaan. Ia berani mengambil risiko, bahkan siap jika usaha yang dilakukan tersebut belum memiliki nilai perhatian di pasar (Suryana 2014).

Dengan demikian kewirausahaan berkaitan dengan karakter seseorang. Yang dibutuhkan oleh wirausahawan itu sangat multidimensional sehingga bersifat holistic. ByGrave telah menjelaskan beberapa karakter tersebut. Dream (mimpi), yaitu seorang wirausaha mempunyai visi keinginan terhadap 
masa depan pribadi dan bisnisnya serta mempunyai kemampuan untuk mewujudkan impiannya. Decisiveness (tegas), yaitu seorang wirausaha adalah orang yang tidak bekerja lambat. Kecepatan dan ketepatan mengambil adalah faktor kunci dalam kesuksesan bisnisnya. Doers (pelaku usaha), yaitu seorang wirausaha dalam membuat keputusan akan langsung menindaklanjuti. Mereka melaksanakan kegiatannya secepat mungkin dan tidak menundanunda kesempatan yang baik dalam bisnisnya. Determination (ketetapan hati) yaitu seorang wirausaha melaksanakan kegiatannya dengan penuh perhatian.

Karakter dari ByGrave dijabarkan lebih lanjut oleh Basrowi (Basrowi 2011). Dedication (pengabdian) yaitu seorang wirausaha dedikasi terhadap bisnisnya sangat tinggi, kadang-kadang mengorbankan kepentingan keluarga untuk sementara, tidak mengenal lelah dan semua perhatian dan kegiatannya dipusatkan semata-mata untuk kegiatan bisnisnya. Devotion (kesetian), yaitu mencintai pekerjaan bisnisnya dan produk yang dihasilkan. Details (detil), yaitu seorang wirausaha sangat memerhatikan faktor-faktor kritis secara rinci. Destiny (takdir), yaitu bertanggung jawab terhadap nasib dan tujuan yang hendak dicapainya, bebas dan tidak mau tergantung kepada orang lain. Dollars (dolar), yaitu seorang wirausaha tidak mengutamakan mencapai kekayaan, motivasinya bukan karena uang. Uang dianggap sebagai ukuran kesuksesan bisnisnya dan berasumsi jika berhasil dalam bisnisnya maka ia pantas mendapat laba, bonus, atau hadiah. Distribute (distribusi), yaitu bersedia mendistribusikan kepemilikan bisnisnya kepada orang kepercayaannya yaitu orang-orang yang kritis dan mau diajak untuk mencapai sukses dalam bidang bisnis.

Scarborough dan Zimmerer meski dalam ungkapan berbeda namun memiliki pandangan yang sama dengan ByGrave. Suryana ( 2014) kemudian memerasnya menjadi enam karakter penting bagai keberhasilan wirausaha. Percaya diri, Merupakan suatu paduan sikap dan kenyakinan seseorang dalam menghadapi tugas atau pekerjaan. Kepercayaan diri merupakan landasan yang kuat untuk meningkatkan karsa dan karya seseorang. Karakter orientasi ke masa depan juga penting. Meskipun terdapat resiko yang mungkin terjadi, ia tetap tabah untuk mencari peluang dan tantangan demi pembaharuan masa depan. Pandangan yang jauh ke depan membuat wirausahawan tidak cepat puas dengan karsa dan karya yang sudah ada saat ini. Karakter berani mengambil resiko juga diakui sebagai salah satu nilai utama dalam kewirausahaan. wirausahawan yang tidak mau menghadapi risiko akan sukar memulai atau berinisiatif. Menurut Angelita S. Bajaro, seorang wirausahawan yang berani menanggung resiko adalah orang yang 
selalu ingin jadi pemenang dan memenangkan dengan cara yang baik. Yang terakhir adalah kreativitas dan inovasi untuk menunjukkan keaslian dan kebaruan. Kreativitas adalah kemampuan untuk berpikir yang baru dan berbeda, sedangkan inovasi adalah kemampuan untuk bertindak yang baru dan berbeda. Menurut Levitt di Suryana (Suryana 2014) menjelaskan inovasi dan kreativitas lebih mengarah pada konsep berpikir dan bertindak yang baru. Kreatifitas adalah kemampuan menciptakan gagasan dan menemukan cara baru dalam melihat permasalahan dan peluang yang ada. Sementara inovasi adalah kemampuan mengaplikasikan solusi yang kreatif terhadap permasalahan dan peluang yang ada untuk lebih memakmurkan kehidupan masyarakat. Jadi, kreativitas adalah kemampuan menciptakan gagasan baru, sedangkan inovasi adalah melakukan sesuatu yang baru.

Kesimpulannya kewirausahaan adalah penerapan dari kreatifitas dan inovatif yang menjadi dasar untuk peluang dalam suatu bisnis dan dalam kewirausahaan terdapat berbagai karakteristik yang mengikuti seperti kemandirian, tanggung jawab, percaya diri, motif berprestasi, berorientasi pada masa depan, berwawasan luas, serta memiliki semangat dan gairah untuk bekerja keras dalam menjalankan suatu kegiatan bisnis.

Selain karakter, kewirausahaan juga dipengaruhi oleh minat seseorang. Minat berwirausaha dapat dilihat dari ketersediaan untuk bekerja keras dan tekun untuk mencapai kemajuan usahanya, kesediaan menanggung macammacam resiko yang berkaitan dengan tindakan berusaha yang dilakukannya, bersedia menempuh jalur dan cara baru untuk mencapai apa yang di inginkan. Menurut Santosa pada tulisan Suryamananim, minat entrepreneur adalah gejala psikis untuk memusatkan perhatian dan berbuat sesuatu terhadap wirausaha itu dengan perasaan senang karena memberikan manfaat bagi dirinya. Intinya dari pendapat tersebut adalah pemusatan perhatian yang disertai rasa senang.

Bygrave di Alma (2011) menjabarkan minat berwirausaha tidak dibawa sejak lahir tapi tumbuh dan berkembang sesuai dengan faktor-faktor yang mempengaruhi. Faktor yang mempengaruhi tumbuhnya keputusan untuk berwirausaha merupakan hasil interaksi dari beberapa faktor yaitu karakter kepribadian seseorang dan lingkungannya. Dari situ, timbul minat seseorang menjadi wira usahawan.

Minat berwirausaha kemudian berupa keinginan, ketertarikan, serta kesediaan individu melalui ide-ide yang dimiliki untuk berkemauan atau bekerja keras untuk berusaha memenuhi kebutuhan hidupnya, tanpa merasa takut dengan resiko yang akan terjadi, dapat menerima tantangan, percaya 
diri, kreatif, dan inovatif serta mempunyai kemampuan dan keterampilan untuk memenuhi kebutuhan.

Pergerakan dan perubahan minat dalam diri seseorang bisa muncul atau tenggelam karena beberapa factor. Crow dan Crow (2005) telah menjabarkannya. The factor inner urge adalah rangsangan yang datang dari lingkungan atau ruang lingkup yang sesuai dengan keinginan atau kebutuhan seseorang akan mudah menimbulkan minat. The factor of social motive adalah minat seseorang terhadap obyek atau sesuatu hal, disamping hal dipengaruhi oleh faktor dalam diri manusia juga dipengaruhi oleh motif sosial. Emotional factor adalah faktor perasaan dan emosi mempunyai pengaruh terhadap obyek misal perjalanan sukses yang dipakai individu dalam suatu kegiatan tertentu dapat membangkitkan perasaan senang dan dapat menambah semangat atau kuatnya minat dalam kegiatan tersebut. Sementara Sabri hanya membaginya menjadi dua jenis (Sabri 1996). Faktor Internal yaitu segenap pikiran emosi dan persoalan dari dalam diri seseorang yang mempengaruhi minat sehingga tidak dapat dipusatkan. Contohnya : minat, ingatan, motivasi, dan kemauan. Faktor Eksternal yaitu faktor yang berasal dari luar diri seseorang yang dapat mempengaruhi minatnya. Contohnya : lingkungan sekitar, sarana, prasarana, dan fasilitas yang digunakan.

\section{Pendidikan Kewirausahaan Islam dalam Keluarga}

Untuk menumbuhkan karakter jiwa dan minat kewirausahaan pada jiwa seseorang muslim bisa dalam berbagai bentuk. Namun para pakar menyepakati bahwa proses pendidikan adalah sarana paling penting. Metode pendidikan yang makin efisien dan efektif diharapkan bisa mengubah sikap dan tingkah laku dalam berbagai aspek kehidupan. Pada level pendidikan dasar, arti penting kemandirian bisa ditekankan baik dalam pendidikan intra maupun ekstra kurikuler (Prastomo et al. 2019).

Di berbagai negara akhir-akhir ini telah berkembang pesat nsformasi pengetahuan entrepreneurship melalui lembaga pendidikan dari tingkat sekolah dasar sampai perguruan tinggi, bahkan di berbagai kursus bisnis (Djakfar 2007). Ruang non-formal juga telah menjadi perhatian agar jiwa kewirausahaan teresap dalam pribadi-pribadi dalam masyarakat (Musaropah et al. 2019). Wiyatno (2009) menguatkannya dengan menujukkan pandangan dari Jack dan Anderson.

Pendidikan entrepreneurship mulai berkembang sekitar tahun 60-an yang lalu di Amerika Serikat oleh Katz. pada tahun 1975 telah lebih dari seratus perguruan tinggi di Amerika serikat yang menawarkan mata kuliah entrepreneurship. Adapun konsentrasi entrepreneurship pertama kali pada tahu $\mathrm{n}$ 
1968 di Babson College yang kemudian diikuti oleh Universitas Of California pada tahun 1972. Saat ini berbagai Universitas besar di Amerika Serikat. Di Indonesia pendidikan entrepreneurship mulai digalakkan pada tahun 2000-an oleh Direktorat Jendral Pendidikan Tinggi mendorong berkembangnya pendidikan entrepreneurship, diantaranya melalui pendanaan kegiatan mahasiswa dalam bidang entrepreneurship.(Wijatno 2009)

Menurut Basrowi (2011) pendidikan kewirausahaan di perguruan tinggi menerapkan prinsip-prinsip dan metodologi kearah pembentukan kecakapan hidup (life skill) pada peserta didiknya melalui kurikulum yang dikembangkan. Prosesnya melibatkan usaha-usaha yang secara sadar dan sistematis untuk mencapai taraf hidup atau kemajuan yang lebih baik. Sebagai upaya menginternalisasikan jiwa dan mental kewirausahaan baik melalui institusi pendidikan maupun institusi lain seperti lembaga pelatihan, training dan sebagainya.

Meski demikian, karakter dan minat adalah sesuatu yang tidak terjadi dalam sekejap. Pembentukannya memerlukan proses yang panjang. jiwa mandiri yang memiliki karakter, pengetahuan, pemahaman dan ketrampilan kewirausahaan sebagai calon seorang entrepreneur Islam harus mengenalinya sejak usia dini. Allah SWT berfirman:

"Hai orang-orang beriman apabila kamu dikatakan kepadamu: "Berlapang-lapanglah dalam majlis", Maka lapangkanlah niscaya Allah akan memberi kelapangan untukmu. Dan apabila dikatakan: "Berdirilah kamu", Maka berdirilah, niscaya Allah akan meninggikan orang-orang yang beriman di antaramu dan orang-orang yang diberi ilmu pengetahuan beberapa derajat. dan Allah Maha mengetahui apa yang kamu kerjakan." (QS Al-Mujadalah: 11)

Ayat tersebut menjelaskan keutamaan orang-orang beriman dan berilmu pengetahuan. Derajat orang-orang yang beriman dan berpengetahuan terangkat oleh Allah SWT. Mukmin menjadi paling mulia karena taat kepada-Nya. 'Alim dihormati oleh orang lain karena kemampuannya melakukan atau mengelola sesuatu atau apa saja yang terjadi dalam kehidupan. Karena itu, menurut Bahri (2018), kewirausahaan Islam memiliki dua dimensi vertical yang berhubungan dengan Allah dan horizontal yang berpijak pada relasi dengan sesama.

Dua karakter penting yang dianjurkan Quran dalam berwirausaha tidak bisa diperoleh seseorang dalam sekejap dalam lingkungan yang terbatas. Dalam konteks pengembangan kewirausahaan, Hasbulloh telah menguraikan arti penting lingkungan keluarga. Hubungan sosial pertama kali dimulai 
adalah dalam keluarga. disinilah anak pertama kali mengenal lingkungan sosial dan budayanya, juga mengenal seluruh anggota keluarganya ayah, ibu dan saudara-saudaranya sampai akhirnya anak itu mengenal dirinya sendiri. Keluarga merupakan institusi yang paling penting pengaruhnya terhadap proses sosialisasi manusia. Proses sosialisasi dalam keluarga dapat dilakukan baik secara formal maupun informal. Proses sosialisasi formal dikerjakan melalui proses pendidikan dan pengajaran, sedangkan proses sosialisasi informal dikerjakan lewat proses interaksi yang dilakukan secara tidak sengaja.(Narwoko dan Suyanto 2004)

ByGrave di Alma (2011) menyebut keluarga termasuk faktor sosiologis. Kamal dan Thoyyibah (Kamal dan Thoyyibah 2020) memasukkan dalam factor kondisi lingkungan dimana entrepreneurial process terjadi dan diperkuat dengan keberadaannya. Oktarina dkk. (Oktarina et al. 2019) mengakui Orang tua atau keluarga merupakan peletak dasar bagi persiapan anak anak agar dimasa yang akan datang dapat menjadi pekerjayang efektif.

Keluarga merupakan lingkungan pendidikan yang pertama, karena dalam keluarga inilah anak pertama-tama mendapatkan didikan dan bimbingan. Lingkungan keluarga adalah lingkungan pertama seseorang dalam kehidupanya. Kelompok masyarakat terkecil itu yang terdiri dari ayah, ibu, anak, dan anggota keluarga yang lain. Bagi seorang anak, keluarga merupakan persekutuan hidup pada lingkungan keluarga tempat dimana menjadi diri pribadi atau diri sendiri. Keluarga juga merupakan wadah bagi anak dalam konteks proses belajarnya untuk mengembangkan dan membentuk diri dalam fungsi sosialnya. (Hasbullah 1988)

Fungsi dan peranan pendidikan dalam lingkungan keluarga. Di situlah terdapat pengalaman pertama masa kanak-kanak yang merupakan faktor penting dalam perkembangan pribadi anak. dari sinilah keseimbangan jiwa di dalam perkembangan individu selanjutnya ditentukan. Pendidikan keluarga ini menjamin kehidupan emosional anak. Kehidupan emosional atau kebutuhan akan rasa kasih sayang dapat dipenuhi atau dapat berkembang dengan baik, hal ini dikarenakan adanya hubungan darah antara pendidik dengan anak didik, sebab orang tua hanya menghadapi sedikit anak didik dan karena hubungan tadi didasarkan atas rasa cinta kasih sayang murni.

Kepentingan lain adalah penanaman dasar-dasar pendidikan sosial Dalam kehidupan keluarga merupakan basis yang sangat penting dalam peletakan dasar-dasar pendidikan sosial anak. Sebab pada dasarnya keluarga merupakan lembaga sosial resmi yang minimal terdiri ayah, ibu dan anak. Penanaman dasar pendidikan moral dan agama juga diawali dari keluarga. Di 
dalam keluarga juga merupakan penanaman utama dasar-dasar moral bagi anak yang biasanya tercermin dalam sikap dan perilaku orang tua sebagai teladan yang dapat dicontoh anak. Keluarga sebagai lembaga pendidikan pertama dan utama, disamping sangat menentukan dalam menanamkan dasar-dasar moral yang tidak kalah pentingnya adalah berperan besar dalam proses internalisasi dan transpormasi nilai-nilai keagamaan ke dalam pribadi anak.(Hasbullah 1988)

Keluarga merupakan tempat belajar bagi anak dalam kesedaran beragama terutama segala sikap untuk berbakti kepada Tuhan sebagai perwujudan nilai hidup yang tertinggi (Arifudin et al. 2019). Hal ini membuktikan segala fungsi dan peran orang tua dalam keluarga dapat mempengaruhi seorang anak dalam berkarir atau berwirausaha. Orang tua adalah pihak yang betanggung jawab penuh dalam proses ini. Salah satu unsur kepribadian adalah minat. Minat berwirausaha akan terbentuk apabila keluarga memberikan pengaruh postif terhadap minat tersebut, karena sikap dan aktifitas sesama anggota keluarga saling mempengaruhi baik secara langsung maupun tidak langsung. Orang tua yang berwirausaha dalam bidang tertentu dapat menimbulkan minat anaknya untuk berwirausaha dalam yang sama pula.

Suhartini (2011) berargumentasi bahwa keluarga merupakan tempat belajar bagi anak dalam segala sikap untuk berbakti kepada Tuhan sebagai perwujudan nilai hidup yang tertinggi. Hal ini membuktikan segala fungsi dan peran orang tua dalam keluarga dapat mempengaruhi seorang anak dalam berkarir atau berwirausaha. Orang tua adalah pihak yang betanggung jawab penuh dalam proses ini baik secara langsung maupun tidak langsung. Orang tua yang berwirausaha dalam bidang tertentu dapat menimbulkan minat anaknya untuk berwirausaha dalam yang sama pula.

\section{Penutup}

Pendidikan keluarga menjadi ruang awal bagi penanaman karakter dan minat anggotanya dalam berwira usaha. Keluarga bahkan memberikan pengetahuan dan keterampilan yang sesuai dengan bidang kewirausahaan. Hal itu akan lebih baik apabila orang tua juga telah memilikinya. Jika sebagian besar keluarga rata-rata bekerja sebagai wirausaha, maka besar kemungkinan keturunannya dapat mengikuti mereka untuk terjun sebagai wirausaha. Hal ini dapat terjadi karena keluarga merupakan tempat mendapatkan pendidikan yang pertama bagi anak dan didalamnya meliputi kondisi-kondisi dalam dunia yang dapat mempengaruhi tingkah laku anak dan anak akan tumbuh dan berkembang menjadi dewasa. Dengan begitu 
keluarga memberikan pengaruh yang positif terhadap minat berwirausaha.

\section{Daftar Pustaka}

Alma, Buchari. 2011. Kewirausahaan. Bandung: Alfabeta.

Arifin, Zainul. 2003. Dasar-Dasar Manajemen Bank Syari'ah. Jakarta: Alvabet.

Arifudin, Wahyu Amin, Nurul Fatihah, Ahmad Echsan, Lailatul Maftuhah, Difla Nadjih, dan Agus Pandoman. 2019. "Kesadaran Beragama Pelaku Pariwisata di Kawasan Malioboro." Nuansa Akademik: Jurnal Pembangunan Masyarakat 4(2):117-32.

Bahri, Bahri. 2018. "Kewirausahaan Islam: Penerapan Konsep Berwirausaha dan Bertransaksi Syariah dengan Metode Dimensi Vertikal (Hablumminallah) dan Dimensi Horizontal (Hablumminannas)." Maro: Jurnal Ekonomi syariah dan Bisnis 1(2):67-86.

Basrowi. 2011. Kewirausahaan untuk Perguruan Tinggi. Bogor: Ghalia Indonesia.

Crow, L. D., dan A. Crow. 2005. Psikologi Pendidikan. Yogyakarta: Penerbit Nur Cahya.

Djakfar, Muhammad. 2007. Agama, Etika, dan Ekonomi Wacana Menuju Pengembangan Ekonomi Rabbaniyah. Malang: UIN Malang Press.

Fahmi, Irham. n.d. Kewirausahaan Teori, Kasus dan Solusi. Bandung.

Frinces, Z. Heflin. 2011. Be An Entreprenuer, Jadilah Seorang Wirausaha. Yogyakarta: Graha Ilmu.

Gitosardjono, Sukamdani Sahid. 2013. Wirausaha Berbasis Islam \& Kebudayaan. Jakarta: Pustaka Bisnis Indonesia.

Hasbullah. 1988. Dasar-dasar Ilmu Pendidikan. Jakarta: PT Raja Grafindo Persada.

Kamal, Al Haq, dan Nasirothut Thoyyibah. 2020. "Analisis Faktor-Faktor Yang Mempengaruhi Minat Berwirausaha Santri Pondok Pesantren." AtTaqaddum 12(1):75. doi: 10.21580/at.v12i1.5330.

Kamaluddin Kamaluddin. 2019. "KEWIRAUSAHAAN DALAM PANDANGAN ISLAM." Hal. 302-10 in Prosiding Seminar Nasional Kewirausahaan. Vol. 1.

Musaropah, Umi, Suharto Suharto, Daluti Delimanugari, Agus Suprianto, Rubini Rubini, Retno Kurnianingsih, dan Citra Ayudiati. 2019. "Pengembangan Kewirausahaan Berbasis Industri Kreatif Bagi Jamaah Wanita Majelis Taklim Di Desa Kepek." Nuansa Akademik: Jurnal Pembangunan Masyarakat 4(2):79-90.

Nadjib H., Ahmad, Muh. Jamaluddin, Hilman Haroen, Taufik Nugroho, dan Paiman Paiman. 2019. "Penanaman Nilai-Nilai Kemasyarakatan Di Pesantren Modern." Nuansa Akademik Jurnal Pembangunan Masyarakat 4(1):17-32.

Narwoko, J. Dw., dan Bagong Suyanto. 2004. Sosiologi: Teks Pengantar dan Terapan. Jakarta: Kencana.

Nugroho, Taufik. 2017. "Reorientasi Peranan Pesantren Pada Era Pembangunan Menuju Partisipasi Pemberdayaan Masyarakat Bawah." Ulumuddin: Jurnal Ilmu-ilmu Keislaman 7(2):147-55.

Oktarina, Harti, Adnan Agung, dan Sitti Hajar Aswad. 2019. "Pengaruh 
Lingkungan Keluarga Terhadap Minat Berwirausaha Mahasiswa Pendidikan Ekonomi STKIP Pembangunan Indonesia." Hal. 49-54 in SEMINAR NASIONAL EKONOMI DAN BISNIS. Vol. 1.

Prastomo, Wiranthi, Muhiyatul Huliyah, M. Nasrudin, Intan Kusumawati, dan AN Ari Bowo. 2019. "Hizbul Wathan Bagi Pendidikan Kemandirian Tingkat Sekolah Dasar." Nuansa Akademik Jurnal Pembangunan Masyarakat 4(1):47-62.

Rusdiana. 2014. Kewirausahaan Teori dan Praktik. Bandung: CV Pustaka Setia. Sabri, M. Alisuf. 1996. Psikologi pendidikan. Jakarta: Pedoman Ilmu Jaya.

Suhartini, Yati. 2011. "Analisis Faktor-faktor yang mempengaruhi Minat Mahasiswa dalam Berwiraswasta." Jurnal Akmenika UPY 7.

Suryana. 2014. Kewirausahaan Kiat dan Proses Menuju Sukses. Jakarta: Salemba Empat.

Wijatno, Serian. 2009. Pengantar Entrepreneurship. Jakarta: Gramedia. 